\title{
KEMAMPUAN MENULIS KARYA ILMIAH MAHASISWA CALON GURU SEKOLAH DASAR MELALUI PENERAPAN METODE DRILL
}

\author{
Suratman $^{1}$, Ilyas $^{2}$, Mariamah $^{3}$ \\ ${ }_{1,2,3}$ STKIP Taman Siswa Bima \\ ${ }^{1}$ mariamahmariamah85@yahoo.co.id
}

\begin{abstract}
The ability to write is very important to have and writing activities can be used as a culture, because with this ability one can express ideas and ideas systematically and sequentially in the form of scientific work, and can broaden horizons and encourage writers to improve thinking skills. The resulting written work will also bind the writer's ideas, ideas and creativity. The reality is that the use of Indonesian grammar is not standardized, the use of punctuation marks is not correct and scientific principles. Written ideas have not been systematic, writing activities still make prospective elementary school teacher students a burden that is difficult to complete. So this research aims to determine the writing ability of students after applying the drill method. This type of research is a descriptive study with 70 students as research subjects as semeseter VIA and B in the PGSD department. The instrument used was a test instrument in the form of a scientific paper writing test in the form of a research proposal. Data were analyzed descriptively and categorized. The results showed that the writing skills of class VI-A students were in three categories, namely the very good, good and good enough categories. Meanwhile, class B falls into two categories, namely good and good enough.
\end{abstract}

Keywords: drill methods; prospective elementary school teacher students; scientific work; writing skills

\begin{abstract}
Abstrak
Kemampuan menulis sangat penting untuk dimiliki serta kegiatan menulis dapat dijadikan sebagai budaya, sebab dengan kemampuan tersebut seseorang dapat menuangkan ide-ide dan gagasan dengan sistematis dan runtun dalam bentuk karya ilmiah, serta dapat memperluas cakrawala dan mendorong penulis untuk meningkatkan kemampuan berpikir. Karya tulis yang dihasilkan juga akan menjadi pengikat gagasan, ide dan kreatifitas yang penulis miliki. Realita yang ditemukan bahwa penggunaan tata bahasa Indonesia yang belum baku, penggunaan tanda baca yang belum tepat serta kaida-kaidah ilmiah. Ide-ide yang ditulis belum sistematis, aktifitas menulis masih membuat mahasiswa calon guru sekolah dasar menjadi beban yang sulit untuk diselesaikan. Sehingga penelitian ini bertujuan untuk mengetahui kemampuan menulis mahasiswa setelah menerapkan metode drill. Jenis penelitian ini adalah penelitian deskriptif dengan subjek penelitian mahasiswa semeseter VIA dan B pada jurusan PGSD yang berjumlah 70 orang. Instrument yang digunakan adalah instrument tes berupa tes menulis karya ilmiah berbentuk proposal penelitian. Data dianalisis secara deskriptif dan dibuat pengkategorian. Hasil penelitian menunjukan bahwa kemampuan menulis mahasiswa kelas VI-A berada pada tiga kategori yaitu pada kategori sangat baik, baik dan cukup baik. Sedangkan pada kelas B berada pada dua kategori yaitu kategori baik dan cukup baik.
\end{abstract}

Kata Kunci: karya ilmiah; kemampuan menulis; mahasiswa calon guru SD; metode drill

\begin{tabular}{llll}
\hline Received & $: 2020-07-29$ & Approved & $: 2020-11-29$ \\
Reviesed & $: 2020-11-05$ & Published & $: 2021-01-31$ \\
\hline
\end{tabular}

Jurnal Cakrawala Pendas is licensed under a Creative Commons Attribution-

ShareAlike 4.0 International License.

\section{Pendahuluan}

Dalam ilmu bahasa, terdapat empat keterampilan yang harus dikuasai oleh mahasiswa seperti keterampilan membaca, menulis, mendengarkan dan berbicara. Keterampilan ini bukan saja untuk dikuasai oleh mahasiswa pada jurusan bahasa, akan tetapi perlu untuk dikuasai oleh seluruh mahasiswa. Kenyataan yang terjadi bahwa kemampuan menulis mahasiswa secara umum masih dianggap kurang. Berdasarkan hasil penelitian Ansori (2017) 
dan Kapka et al (2001) bahwa kemampuan menulis mahasiswa tidak merata dan masih lemah. Vera Sardila (2015) pada penelitiannya menunjukan bahwa kemampuan menulis mahasiswa masih kurang, hal ini dilihat dari karya tulis yang dihasilkan mahasiswa berupa makalah atau tugas lainnya yang belum memenuhi standar. (Persadha, 2016) menyatakan bahwa kemampuan menulis mahasiswa Indonesia masih dibawah standar, hal ini dilihat dari publikasi mahasiswa yang minim. Menurut (Cahyani, 2010) bahwa mahasiswa kesulitan mengungkapkan idenya, mengatur paragraf dengan benar, penggunaan bahasa yang belum tepat. Menurut (Kellogg, 2008) bahwa menulis teks yang efektif dalam sebuah karya ilmiah masih dirasakan sulit oleh mahasiswa. Berbagai permasalah-permasalah yang ditemukan dalam penelitian terdahulu tidak jauh berbeda dengan permasalahan yang ditemukan pada mahasiswa Di STKIP Taman Siswa Bima.

Pada jurusan PGSD Di STKIP Taman Siswa Bima memiliki matakuliah metodologi penelitian yang merupakan mata kuliah dengan outputnya adalah mahasiswa mampu menulis proposal penelitian. Selain mata kuliah tersebut, mahasiswa juga memiliki mata kuliah skripsi sebagai bentuk tugas akhir. Sehingga mahasiswa sangat diperlukan untuk dibekali dengan keterampilan menulis yang baik dan benar. Realita yang ditemukan peneliti seperti pada saat mengampu mata kuliah metodologi penelitian bahwa penggunaan tata bahasa Indonesia yang belum baku, penggunaan tanda baca yang belum tepat serta kaida-kaidah ilmiah dalam penulisan proposal masih kurang. Ide-ide yang ditulis belum sistematis, aktifitas menulis masih membuat mahasiswa menjadi beban yang sulit untuk diselesaikan. Hal ini juga terjadi pada mahasiswa semester VI yang sedang mengampu mata kuliah metodologi, disaat mahasiswa diberikan tugas untuk menulis karya ilmiah (proposal), tidak semua mahasiswa mengerjakan dengan baik dan tepat waktu. Dapat dipersentasekan bahwa $75 \%$ mengumpulkan tugas dengan terlambat, selain itu, mahasiswa dalam menulis proposal masih ditemukan uraian ide tidak sistematis, serta tidak mengikuti sitematika dengan baik. Permasalahan tersebut disebabkan karena kemampuan menulis mahasiswa masih belum maksimal. Karena kemampuan menulis begitu pentingnya untuk dimiliki oleh mahasiswa, sangat diperlukan suatu bentuk usaha yang harus dilakukan untuk mengembangkan kemampuan menulis sehingga mahasiswa dapat menuliskan ide-ide yang dimiliki dalam bentuk karya ilmiah seprti menulis tugas akhir (skripsi) dengan baik dan benar. Keterampilan menulis merupakan salah satu keterampilan dasar dalam ilmu Bahasa, sebagai bentuk usaha sesorang dalam mengembangkan serta menyebarluaskan gagasan/ide yang dimiliki, untuk meningkatkan kualitas diri dan bangsa serta sebagai sumber pengembangan iptek disegala bidang. Menulis juga dapat membuat seseorang untuk mengembangkan kemampuan berpikir, berbahasa secara tertib, memperluas cakrawala serta membuat seseorang untuk mengenali dirinya. Mahasiswa yang memiliki kemampuan menulis yang baik akan mempermudah dirinya untuk menulis proposal penelitian, menulis buku serta jurnal. Karena begitu pentingnya kemampuan menulis ini sehingga sudah ada berbagai penelitian yang sudah dilakukan seperti dalam penelitian Sunimbar (2018), Kurniawan (2016), Seran et al (2020), Rahmawati \& Thalia (2012), Gunawan, Pupun Nuryani et al (2019), Gereda (2014), Mujianto et al (2017), Vera Sardila (2015), Cahyani (2010). Dari berbagai penelitian yang sudah dilakukan ini hanya sebatas pada kemampuan menulis mahasiswa secara umum tanpa ada indikator penilaian yang ditentukan. Dalam penelitian yang dilaksanakan ini sudah menentukan indikator penilaian yang akan diukur dari kemmapuan menulis mahasiswa. Adapun indicator yang ditentukan seperti 1) Kesesuaian dengan sistimatika, 2) Ide dan pengetahuan yang dituangkan dalam tulisan tepat dan benar sesuai dengan masing-masing aitem pada sistimatika, 3) Penggunaan tatabahasa yang benar, 4) Kemenarikan dari tulisan

Kemampuan menulis adalah suatu kemampuan dengan proses menuangkan ide, gagasan dan pikiran serta pengalaman dalam bentuk tulisan, menulis ini merupakan keterampilan bahasa yang bersifa aktif dengan kegiatan encoding untuk menciptakan bahasa bagi para pembaca secara tertulis dengan tujuan untuk memberitahukan sejumlah informasi, meyakinkan pembaca, sebagai penghibur, dan mengekspresikan perasaan sebagai bentuk merespon fenomena-fenomena dalam kehidupan sehari-hari Zulkarnaini (2014). Menurut 
Tarigan bahwa menulis adalah suatu aktivitas yang ekspresif dan produktif. Aktivitasbahasa yang produktif merupakan aktivitas untuk menyampaikan ide/gagasan, pikiran atau perasaan hati oleh pihak penutur melalui sarana menulis Tarigan (2018). Menurut Iskandarwassid dan Sunendar bahwa keterampilan menulis merupkan keterampilan yang sulit dibandingkan dengan keterampilan yang lain karena dalam menulis menghendaki semua unsur kebahasaan harus dikuasai Wassid \& Sunendar (2008). Tujuan menulis pada hakekatnya yaitu untuk mewujudkan gagasan penulis dengan penyampaian secara tertulis untuk dibaca oleh pembaca. Tulisan tentu harus dapat dimengerti dan mudah dipahami oleh pembaca serta buah pikiran dari tulisan dapat dimahami secara mendalam dalam pikiran para pembaca. Menuru Semi bahwa tujuan menulis adalah: a) untuk menceritkan sesuatu, b) sebagai pengarahan atau petunjuk, c) untuk menjelaskan sesuatu, d) untuk meyakinkan dan e) untuk merangkum para pembaca.

Tulisan ilmiah yaitu suatu karangan yang menampilkan masalah atau suatu pengetahuan keilmuan dan ditulis menurut tatabahasa yang baik dan benar. Tulisan tersebut biasanya disebut makalah atau proposal penelitian yang menjadi tugas perkuliahan mahasiswa untuk dikerjakan Zulkarnaini (2014). Karya ilmiah yang dimaksudkan dalam penelitian ini adalah proposal penelitian, mahasiswa akan menulis ide-ide mereka dengan mengikuti sistimatika penulisan proposal di STKIP Taman Siswa Bima. Adapun sitematika penulisan proposal terdiri dari: 1) halaman judul, 2) kata pengantar, 3) daftar isi, 4) daftar tabel/gambar jika ada, 5) BAB I Pendahuluan yang terdiri dari latar belakang masalah, identifikasi masalah, pembatasan masalah, rumusan masalah, tujuan penelitian dan manfaat penelitian, 5) BAB II Kajian Pustaka yang terdiri dari kajian teori, penelitian yang relevan, kerangka piker dan hipotesis, 6) BAB III Metode Penelitian yang terdiri dari jenis penelitian, peran peneliti, waktu dan tempat penelitian, subyek penelitian, instrumen, prosedur pengmpulan data, analisis data dan indikator keberhasilan, 7) daftar pustaka. Dari penjelasan di atas, dapat dibuat kesimpulan bahwa indikator peneilaian karya tulis ilmiah terdiri dari: 1) Kesesuaian dengan sistimatika, 2) Ide dan pengetahuan yang dituangkan dalam tulisan tepat dan benar sesuai dengan masing-masing aitem pada sistimatika, 3) Penggunaan tatabahasa yang benar, 4) Kemenarikan dari tulisan. Dari keempat indikator yang ditetapkan ini sangat sesuai dengan kemampuan yang diharapkan dari mahasiswa sebagai calon guru sekolah dasar, sehingga nantinya dapat menjadi guru yang kreatif dan inovatif dalam menyusun karya ilmiah untuk diajarkan kepada para peserta didik.

Berdasarkan uraian masalah dan pentingnya keterampilan menulis di atas, sehingga dalam penelitian ini memilih solusi dengan menerapkan metode drill dengan tujuan untuk mengembangkan kemampuan menulis karya ilmia dengan baik dan benar. Menurut Engin (2014) dan Susilo (2020) bahwa penggunaan teknologi dan berbagai metode mengajar yang inovatif akan dapat mendorong mahasiswa untuk lebih aktif. Metode drill merupakan salah satu metode mengajar yang inovatif dimana metode ini banyak memberikan kesempatan kepada mahasiswa untuk berlatih secara terus menerus sehingga dapat menghasilkan suatu keterampilan atau kecakapan tertentu. Metode driil merupakan metode pembelajaran yang memberikan kesempatan kepada mahasiswa secara terus menerus untuk berlatih menulis sehingga mahasiswa akan terbiasa menuangkan ide-ide yang dimiliki dengan sistematis dan tepat Mariamah \& Syarifudin (2018). Menurut Tarigan bahwa keterampilan menulis seseorang tidak datang secara otomatis melainkan harus dengan latihan yang sering dan teratur. Keterampilan menulis mahasiswa tidak diperoleh dengan cara alamiah atau diwarisakn melainkan mahasiswa perlu dilatih secara terus menerus Zulkarnaini (2014). Sehingga sangat cocok metode drill untuk diterapkan agar kemampuan menulis mahasiswa dapat kembangkan. Metode drill merupakan metode yang dapat membangun rutinitas belajar mahasiswa secara berkesinambungan, dikembangkan dengan tujuan membimbing dan melatih mahasiswa dalam menguasai materi. Menurut Lufri et al (2018) bahaw metode drill (latihan) adalah suat cara mengajar yang bagus untuk diterapkan untuk menanamkan kebiasaan tertentu serta sebagai sarana untuk memperoleh keterampilan dari apa yang sudah dipelajari. Metode latihan ini juga dilakukan secara berulang-ulang sehingga terbentuk 
kemampuan yang diharapkan. Praktek juga dilakukan dalam situasi nyata sehingga dapat memberikan pengalaman secara langsung Sianturi et al (2019)

Menurut Solehah dalam tulisan Hadijah bahwa metode drill adalah salah satu cara mengajar yang diterapkan guru dengan cara memberikan latihan berulan-ulang untuk dikerjakan oleh peserta didik agar tujuan pembelajaran tercapai. Sedangkan menurut Delazer et al (2005) bahwa metode drill merupakan metode mengajar yang memberikan tugas atau pekerjaan yang diberikan kepada mahasiswa untuk dikerjakan dengan baik. Latihan yang diberikan akan dapat membuka kesempatan kepada mahasiswa untuk menyelesaikannya, hal ini akan memberikan pengalaman langsung kepada mahasiswa terkait penyelesaian latihan yang diberika Hadijah (2016). Menurut Puspitaningrum bahwa metode drill/ latihan merupakan metode mengajar yang dapat digunakan oleh guru/dosen untuk mengembangkan keterampilan menulis Susilowati et al (2013). Menurut Dzamarah dan Zain dalam tulisan Budiono bahwa metode drill dapat dilakasanakan dalam tiga fase yautu: 1) fase pemberian latihan oleh guru/dosen, 2) fase pengerjaan latihan oleh siswa/mahasiswa dan dosen membimbing para mahasiswa, 3) fase pertanggung jawaban dari mahasiswa Fallis (2013). Berdasarkan teori di atas bahwa metode drill adalah metode mengajar yang memberikan kesempatan seluas-luasnya kepada mahasiswa untuk mengerjakan latihan secara terus menerus agar mencapai tujuan pembelajaran. Dalam penelitian ini, penerapan metode drill dengan tahap pertama adalah memberikan latihan secara berulang-ulang kepada mahasiswa untuk menyusun proposal penelitian BAB I, tahap kedua adalah mengumpulkan hasil kerja untuk dikoreksi. Untuk penyusunan BAB II dan III akan melalui dua tahapan yang sama. Dari permasalahan penelitian yang ditemukan dan solusi yang tawarkan sehingga penelitian ini bertujuan untuk medeskripsikan peningkatan kemampuan menulis mahasiswa melalu metode driil

\section{Metode Penelitian}

Jenis penelitian ini adalah penelitian deskriptif dengan tujuan untuk mendeskripsikan kemampuan menulis mahasiswa calon guru sekolah dasar di STKIP Taman Siswa Bima. Subjek penelitian adalah mahasiswa semeseter VI kelas A dan B yang berjumlah 70 orang mahasiswa. Instrument untuk mengukur kemampuan menulis yang digunakan dalam penelitian ini adalah tes menulis karya ilmiah dalam bentuk menulis proposal penelitian. Karya tulis yang terkumpul akan dikoreksi mengacu pada indikator yang sudah ditetapkan yaitu 1) Kesesuaian dengan sistimatika, 2) Ide dan pengetahuan yang dituangkan dalam tulisan tepat dan benar sesuai dengan masing-masing aitem pada sistimatika, 3) Penggunaan tatabahasa yang benar, 4) Kemenarikan dari tulisan. Data dianalisis sescara deskriptif denga mencari nilai rata-rata, nilai terendah dan tertinggi, hasil analisis secara deksriptif ini akan dikonsultasikan dengan kriteria pada tabel 1. Adapun kriteria kemampuan menulis yang digunakan sebagai berikut:

Tabel 1. Interval kategori kemampuan menulis mahasiswa

\begin{tabular}{cc}
\hline Interval (\%) & Kategori \\
\hline $86-100$ & Sangat baik \\
$71-85$ & Baik \\
$56-70$ & Cukup baik \\
$41-55$ & Kurang baik \\
$\leq 40$ & Tidak baik \\
\hline
\end{tabular}

(Ajwar et al., 2020) 


\section{Hasil dan Pembahasan}

Dari hasil analisis data secara deskriptif diperoleh data hasil tes kemampuan menulis mahasiswa kelas VI-A pada tabel 1 dan deskripsi data untuk kelas IV-B pada tabel 2.

Tabel 2. Descriptive Statistics kelas IV-A

\begin{tabular}{lrrr}
\hline & Minimum & Maximum & \multicolumn{1}{c}{ Mean } \\
\hline Sistimatika & 70.00 & 95.00 & 84.7143 \\
Ide/gagasan & 65.00 & 95.00 & 79.7143 \\
Tatabahasa & 70.00 & 90.00 & 79.2857 \\
Kemenarikan & 70.00 & 95.00 & 82.8571 \\
\hline
\end{tabular}

Tabel 2 diketahui nilai rata-rata untuk aspek sistimiatika sebesar 84.7143, aspek Ide atau gagasan yang dituangkan dalam tuliasan sebesar 79.7143, tatabahasa dengan nilai rata-rata 79.2857 dan aspek kemenarikan dengan rata-rata sebesar 82.8571 .

Tabel 3. Descriptive Statistics kelas IV-B

\begin{tabular}{lccc}
\hline & Minimum & Maximum & Mean \\
\hline Sistimatika & 65.00 & 90.00 & 77.8571 \\
Ide/gagasan & 60.00 & 85.00 & 73.0000 \\
Tatabahasa & 60.00 & 85.00 & 74.5714 \\
Kemenarikan & 60.00 & 90.00 & 72.4286 \\
\hline
\end{tabular}

Tabel 3 diketahui nilai rata-rata untuk aspek sistimiatika sebesar 77.8571, aspek ide atau gagasan yang dituangkan dalam tuliasan sebesar 73.0000, tatabahasa dengan nilai rata-rata 74.5714 dan aspek kemenarikan dengan rata-rata sebesar 72.4286 .

Tabel 4. Kategori kemampuan menulis mahasiswa

\begin{tabular}{ccccc}
\hline Kelas & Interval (\%) & Frekuensi & Persentase & Kategori \\
\hline \multirow{4}{*}{ VI-A } & $86-100$ & 9 & $26 \%$ & Sangat baik \\
& $71-85$ & 25 & $71 \%$ & Baik \\
& $56-70$ & 1 & $3 \%$ & Cukup baik \\
& $41-55$ & 0 & $0 \%$ & Kurang baik \\
& $\leq 40$ & 0 & $0 \%$ & Tidak baik \\
& $86-100$ & 0 & $0 \%$ & Sangat baik \\
VI-B & $71-85$ & 7 & $20 \%$ & Baik \\
& $56-70$ & 28 & $80 \%$ & Cukup baik \\
& $41-55$ & 0 & $0 \%$ & Kurang baik \\
& $\leq 40$ & 0 & $0 \%$ & Tidak baik \\
\hline
\end{tabular}

Data kategori kemampuan menulis mahasiswa dapat diketahui bahwa kelas VI-A terdapat 26\% dengan kategori sangat baik, sedangkan pada kelas VI-B 0\%, kemampuan menulis dengan kategori baik sebesar 71\% sedangakan pada kelas VI-B lebih sedikit dengan persentase $20 \%$. Untuk kategori cukup baik pada kelas VI-B sebesar $80 \%$ dan pada kelas VI-A sebesar $3 \%$.

Berdasarkan hasil penelitian, diketahui bahwa kemampuan menulis karya ilmiah mahasiswa kelas VI-A dan B dengan pembelajaran menggunakan metode drill dengan kategori sangat tinggi, tinggi dan cukup tinggi. Ada empat aspek yang dinilai dari karya 
tulis mahasiswa yaitu aspek sistimatika, aspek ide/gagasan yang ditulis, aspek tata bahasa dan aspek kemenarikan dari tulisan.

Sebelum penerapan metode drill bahwa kemampuan mahasiswa dalam menulis karya ilmiah belum sesuai dengan indikator yang diharapkan. Misalnya mahasiswa menulis tidak sesuai dengan sistimatika yang ada, ide dan gagasan yang dituangkan belum runtun, penggunaan tatabahasa juga masih ditemukan bahasa yang tidak baku, penulisan tanda baca yang belum tepat serta penggunaan kata penghubung yang masih kurang tepat. Kemmapuan-kemampuan ini dapat dikembangkan setelah diterapkannya metode drill. Penerapan metode drill memberikan hasil yang baik dari aspek kemampuan menulis mahasiswa. Metode drill dilaksanakan dengan memberikan waktu sebanyak-banyaknya kepada mahasiswa untuk berlatih menulis secara terus menerus dengan tujuan agar mahasiswa terbiasa dalam menulis serta menguasai tekhnik menulis yang baik. Dari adanya kebiasaan ini mendorong mahasiswa lebih jeli untuk memperhatikan ide-ide yang mereka tulis, jeli dalam penggunaan tata bahasa serta terbiasan dengan sistematika penulisan.

Hasil penelitian ini mendukukung teori yang dipelopori oleh Thorndike, Pavlop, dan Skinner tentang teori Behavioristik yang menyatakan bahwa hasil dari proses pembelajaran yang dilakukan oleh individu dapat dilihat dari perubahan tingkah lakunya. Tingkah laku yang dapat diamati dalam penelitian ini berupa kegiatan latihan dan praktek menulis yang dilakukan mahasiswa. Teori selanjutnya yang didukung dari hasil peneitian ini adalah penelitian Kongskey. Menurut teori ini menyatakan bahwabelajar sebagai perubahan yang terjadi melalui latihan-latihan dan praktek. Dari dua teori ini yang menjadi dasar sehingga diperlukan penerapan metode drill dalam pembelajaran.

Pembelajaran dengan metode latihan dapat memberikan perubahan tingkah laku pada individu yang belajar, tingkah laku tersebut dapat berupa pengetahuan, sikap dan keterampilan. Kegiatan-kegiatan latihan yang diberikan dapat mendorong mahasiswa lebih aktif dalam mengeksplorasikan ide dan pengetahuannya sehingga terbentuk suatu keterampilan. Dalam pembelajaran mahasiswa berperan aktif dan dosen hanya sebagai fasilitator. Metode drill ini selain diterapkan pada pembelajaran dengan materi yang mudah hingga materi yang kompleks. Hal ini juga diterapkan dalam perkuliahan untuk mengembangkan kemampuan menulis mahasiswa yang terdiri dari empat indicator antara lain: 1) Kesesuaian dengan sistimatika, 2) Ide dan pengetahuan yang dituangkan dalam tulisan tepat dan benar sesuai dengan masing-masing aitem pada sistimatika, 3) Penggunaan tatabahasa yang benar, 4) Kemenarikan dari tulisan

Hasil penelitian ini juga mendukung beberapa hasil penelitian sebelumnya seperti hasil penelitian yang dilakukan oleh Muslihah \& Asmara, 2019), Budisantoso (2018), Padlurrahman (2019). Dari beberapa penelitian yang relevan dengan hasil penelitian yang diperoleh. Dimana metode drill ini memberikan hasil yang lebih baik. Hasil penelitian lain juga sudah membuktikan bahwa metode drill ini meberikan hasil yang lebih unggul seperti hasil penelitian yang dilakukan oleh Padlurrahman (2019) bahwa hasil uji t menunjukan hasil belajar teknik penulisan karya ilmiah mahasiswa pada kelas yang diterapkan metode driil lebih baik dibandingkan pada kelas dengan metode tutorial.

Menurut Syafruddin bahwa metode drill merupakan cara mengajar yang membiasakan mahasiswa untuk melakukan kegiatan-kegiatan supaya mahasiswa memiliki kemampuan lebih. Lebih lanjut syafrudin menyampaikan bahwa drill merupaka metode mengajar dengan mengulang-ulang rangkaian kegiatan yang dilakukan sampai kegiatan tersebut dikuasai. Menuru Padlurrahman (2019) bahwa metode drill suatu upaya agar dapat memantapkan keterampilan asosiasi yang telah diperoleh . Menurut Susilowati et al (2013) bahwa drill merupakan salaha satu cara untuk memberikan latihan kepada mahasisawa terkaita materi yang dipelajari. Menurt Hadijah bahwa metode latihan/drill merupakan pemberian latihan yang berulang-ulang. 


\section{Kesimpulan}

Deskripsi kemampuan menulis karya ilmiah mahasiswa setelah menerapkan metode driil berada pada kategori sangat tinggi, tinggi dan cukup tinggi. Maka konsekuensi logis atau implikasi dari penelitian ini untuk mengembangkan kemampuan menulis mahasiswa calon guru sekolah dasar, diperlukan penerapan metode drill. Sebagai calon guru SD sangat diperlukan untuk memiliki kemampuan menulis yang baik agar nanti dapat diaplikasikan dalam proses pembelajaran

\section{Daftar Pustaka}

Ajwar, M., Faridah, F., \& Mariamah. (2020). Deskripsi Keterampilan Dasar Mengajar Mahasiswa Calon Guru Setelah Menerapkan Metode Inkuiri Terbimbing Pada Materi IPA Dan Matematika. Jurnal Pendidikan MIPA, 10(januari 2020), 35-39.

Ansori. (2017). Peningkatan Kemampuan Menulis Mahasiswa Melalui Model Workshop Dalam Perkuliahan Kepenulisan Pada Program Nonkependidikan Jurusan Pendidikan Bahasa. Journal of Chemical Information and Modeling, 110(9), 1689-1699.

Cahyani, I. (2010). Peningkatan Kemampuan Menulis Makalah Melalui Model Pembelajaran Berbasis Penelitian pada Mata Kuliah Umum Bahasa Indonesia. Sosiohumanika: Jurnal Pendidikan Sains Sosial Dan Kemanusiaan, 3(2), 175-192. http://mindamas-journals.com/index.php/sosiohumanika/article/view/411

Delazer, M., Ischebeck, A., Domahs, F., Zamarian, L., Koppelstaetter, F., Siedentopf, C. M., Kaufmann, L., Benke, T., \& Felber, S. (2005). Learning by strategies and learning by drill - Evidence from an fMRI study. NeuroImage, 25(3), 838-849. https://doi.org/10.1016/j.neuroimage.2004.12.009

Engin, M. (2014). Extending the flipped classroom model: Developing second language writing skills through student-created digital videos. Journal of the Scholarship of Teaching and Learning, 14(5), 12-26. https://doi.org/10.14434/josotlv14i5.12829

Fallis, A. . (2013). Peer Mentoring Membaca Al-Quran Intensif Melalui Metode Talaqqi. Journal of Chemical Information and Modeling, 53(9), 1689-1699. https://doi.org/10.1017/CBO9781107415324.004

Gereda, A. (2014). Kemampuan Menulis Deskripsi Mahasiswa Program Studi Pendidikan Bahasa Dan Sastra Indonesia Universitas Musamus. MAGISTRA: Jurnal Keguruan Dan Ilmu Pendidikan, 2(1), 125-137. https://doi.org/10.35724/magistra.v2i1.325

Gunawan, Pupun Nuryani, D. H., Program, Pedagogik, D., Pendidikan, F. I., \& Indonesia, U. P. (2019). Metode drill untuk meningkatkan kemampuan. Ii, 284-292.

Hadijah. (2016). Penggunaan Metode Latihan Untuk Meningkatkan Kemampuan Menulis Permulaan Siswa Kelas I SDN Sibaluton. Jurnal Kreatif Tadulako, 4(8), 235-249.

Kapka, D., Oberman, D. A., \& Chicago, I. (2001). Improving Student Writing Skills Through The Modeling Of The Writing Process Field-Based Master's Program.

Kellogg, R. T. (2008). Training writing skills: A cognitive developmental perspective. Journal of Writing Research, 1(1), 1-26. https://doi.org/10.17239/jowr-2008.01.01.1

Latif Ansori Kurniawan. (2016). Pembelajaran keterampilan menulis dengan blog: telaah pembelajaran berjarak.

Lufri, Fitri, R., \& Yogica, R. (2018). Effectiveness of concept-based learning model, drawing and drill methods to improve student's ability to understand concepts and high-level thinking in animal development course. Journal of Physics: Conference Series, 1116(5). https://doi.org/10.1088/1742-6596/1116/5/052040

Mariamah \& Syarifudin. (2018). Textbook Development Based On Analysis Of Complex Drill Problem To Develop Students Self Character. InternasionalICST Universit as 


\section{Mataram.}

Mujianto, M., Zubaidi, Z., \& Suprapto YM, Y. (2017). Peningkatan kemampuan menulis karya ilmiah mahasiswa program jaringan telekomunikasi digital ( JTD ) melalui problem based learning. Prosiding Seminar Nasional \#3: Bahasa Dan Sastra Indonesia Dalam Konteks Global, 177-186. https://jurnal.unej.ac.id/index.php/fkipepro/article/view/4868

Muslihah, N. N., \& Asmara, Y. (2019). Penerapan Metode Drill terhadap Peningkatan Kemampuan Menulis Aksara Ulu. Jurnal Kajian Bahasa, Sastra Dan Pengajaran (KIBASP), 2(2), 175-189. https://doi.org/10.31539/kibasp.v2i2.607

Padlurrahman, 2019. (n.d.). Menggunakanfile:///C:/Users/Mariamah/Downloads/13484179-3-PB.pdf Metode Drill and Practice. 14-24.

Persadha, D. A. K. (2016). Studi Kompetensi Kemampuan Menulis Di Kalangan Mahasiswa. Muaddib: Studi Kependidikan Dan Keislaman, 6(1), 1. https://doi.org/10.24269/muaddib.v6n1.2016.1-20

Rahmawati, E. L., \& Thalia, N. (2012). Upaya Meningkatkan Kemampuan Menulis Ilmiah Mahasiswa S1 Fisioterapi UMS Dengan Metode Kolaborasi Pada Tahun Akademik 2012/2013. Jurnal Penelitian Humaniora, 13(2), 178-189.

Seran, W. A., Utomo, D. H., \& Handoyo, B. (2020). Pengaruh Model Pembelajaran Outdoor Study Berbantuan Video Conference terhadap Kemampuan Menulis Karya Ilmiah Mahasiswa. Jurnal Pendidikan, 5(2), 142-152. http://journal.um.ac.id/index.php/jptpp/

Sianturi, G. G. N., Akbar, S., \& Pardede, O. B. (2019). Meningkat Kemampuan Menulis Teks Berita dengan Model Pembelajaran Kooperatif Tipe Stad (Student Team Achievement Divisions) Oleh Siswa Kelas Viii-A SMP Dharma Pancasila Medan Tahun Pelajaran 2018/2019. Tapanuli Journals, 1(2), 357-361.

Sunimbar, S. (2018). Pengaruh Model Pembelajaran (Studi Lapangan-Peta Pikiran) Dan Motivasi Berprestasi Terhadap Keterampilan Menulis Karya Ilmiah Pembelajaran Ips Sd Mahasiswa Pgsd Muhammadiyah Kupang. Jurnal Bidang Pendidikan Dasar, 2(2), 33-43. https://doi.org/10.21067/jbpd.v2i2.2535

Susilo, S. V. (2020). Penggunaan Media Pembelajaran Berbasis Audio Visual Untuk Meningkatkan Hasil Belajar Bahasa Indonesia Di Sekolah Dasar. Jurnal Cakrawala Pendas, 6(2), 108-115.

Susilowati, E., Santoso, S., \& Hamidi, N. (2013). Penggunaan Metode Pembelajaran Drill Sebagai Upaya Meningkatkan Prestasi Belajar Akuntansi. Jupe UNS, 1(3), 1-11. https://jurnal.fkip.uns.ac.id/index.php/ekonomi/article/view/2563

Tarigan, H. G. (2018). Menulis Sebagai Suatu Keterampilan Berbahasa. In Bandung: Angkasa.

Vera Sardila, M. P. (2015). Strategi Pengembangan Linguistik Terapan Melalui Kemampuan Menulis Biografi Dan Autobiografi: Sebuah Upaya Membangun Ketrampilan Menulis Kreatif Mahasiswa. Jurnal Pemikiran Islam, 40(2), 110-117. https://scholar.google.co.id

Zulkarnaini, Z. (2014). Peningkatan Kemampuan Menulis Karya Ilmiah Mahasiswa Pgsd Semester I Melalui Drill Method. None, 1(2), 1-9. 